\title{
British publishers and colonial editions
}

Book or Report Section

Accepted Version

Wilson, N. (2016) British publishers and colonial editions. In: Wilson, N. (ed.) The Book World: Selling and Distributing British Literature. Library of the Written Word. Brill, The Hague. ISBN 9789004315860 Available at

https://centaur.reading.ac.uk/47357/

It is advisable to refer to the publisher's version if you intend to cite from the work. See Guidance on citing.

Publisher: Brill

All outputs in CentAUR are protected by Intellectual Property Rights law, including copyright law. Copyright and IPR is retained by the creators or other copyright holders. Terms and conditions for use of this material are defined in the End User Agreement.

\section{www.reading.ac.uk/centaur}

\section{CentAUR}

Central Archive at the University of Reading

Reading's research outputs online 
Chapter 2

British publishers and colonial editions

\section{Nicola Wilson}

\section{University of Reading}

n.l.wilson@ reading.ac.uk

This is the author final version after peer review corrections, in author's own formatting (i.e. before editing and typesetting by the publisher).

This chapter will appear in the forthcoming edited volume, The Book World: Selling and Distributing British Literature, 1900-40, ed. Nicola Wilson (The Hague, Brill, 2016) 


\section{Chapter 2}

\section{British publishers and colonial editions}

\section{Nicola Wilson}

"[T]he export of English books is going on all the time through many channels and to an extent few realize” (Stanley Unwin, 'English books abroad,' 1935) ${ }^{1}$

Nestling amongst the typed correspondence, private papers and recorded minutes in the archive of the British publishing house of Chatto \& Windus lays a pencil draft for a Cable \& Wireless telegram sent on 7 September 1937:

Published

Melbourne, Perth, Sydney, Wellington

Enchanter's Nightshade Book Society Choice November Chatto. $^{2}$

Enchanter's Nightshade (1937), the fourth published novel by popular author Ann Bridge (Lady Mary Dolling O’Malley, 1889-1974), was one of her “Adriatic novels," a romance and comedy of cultural and generational clashes set amongst the provincial nobility of Italian society. ${ }^{3}$ It was Bridge's third novel selected as "Choice" of the month by the influential British book club, the Book Society Limited, a global distributor with members in over thirty countries. A few days later, on 13 September 1937, Joseph Hicks of Hicks, Smith \& Wright,

\footnotetext{
${ }^{1}$ Stanley Unwin, 'English Books Abroad,' in John Hampden, ed., The Book World (London: Nelson, 1935), pp. 163-80 (p. 180).

${ }^{2}$ Reading, University of Reading Special Collections (hereafter UoR), Chatto \& Windus archive, MS 2444, CW 71/4.

${ }^{3}$ Ann Bridge, Facts and Fictions (London: Chatto \& Windus, 1968), p. 52.
} 
publishers' representatives in Australasia, replied to Chatto from his office in Melbourne, acknowledging the cable and thanking them for "giving us further consideration regarding the marketing business."4 He added later: "Very glad to have the note regarding Enchanter's Nightshade and I think unique for an author to get three books selected by the Book Society."

The serendipitous preservation of this telegram in the publisher's archive frames my concern with the colonial book trade and the impact of distributors upon reading practices and literary culture in this chapter, as well as with the process and practices of archiving and the methodologies of book history research, as explored by other chapters in this book. The hastily jotted down note for a telegram sent out from a busy London publishing house to its agents in Australia and New Zealand is a snapshot of the ephemeral and time-bound, yet regular work-a-day exchanges that underpinned the Anglophone book trade and its global networks of marketing and distribution throughout the first half of the twentieth century. Laying loose amongst typed, more formal, documents that have been carefully edited, cleared out and filed before being deposited in the archive, the pencilled telegram is a reminder and remainder of the international trade in British books in this period. It indicates the significance of global trade to London-based publishers while also capturing the latter's awareness of relaying important marketing news to booksellers and readers in the former colonies with speed and urgency. A precise, twelve word communiqué, it gestures towards important questions about power, cultural exchange and transmission that analysis of the colonial Anglophone book trade necessarily brings to the fore.

Many areas of literary and historical research have over the past few years enjoyed a "transnational turn" and book history is in this sense no exception. Important work by Sydney

\footnotetext{
${ }^{4}$ Joseph Hicks to Harold Raymond, 13 September 1937 (see above, n. 2).

${ }^{5}$ Joseph Hicks to Harold Raymond, 13 October 1937. Ibid. 
Shep, Robert Fraser, Isabel Hofmeyr and many others has challenged national frameworks for explaining the history of books and literature, and demonstrated the very long history of books travelling and moving "without borders." ${ }^{\prime 6}$ Such research has shown how, in Hofmeyr's words, "forms of influence consequently flow in more than one direction and developments are shaped in multiple sites." ${ }^{, 7}$ My starting place in this chapter, which considers patterns of export and distribution and is heavily based on research in the Archives of British Publishing and Printing at the University of Reading, may not seem the most likely place to engage with revisionist, transnational book histories. But the colonial marketplace in the period 1900-40 was a much more important part of the primary audience for new books published and distributed from London than is often recognised, and publishers' archives reveal the significance of bookshops, wholesalers and readers from the former colonies. Recent scholarship on the colonial marketplace and reading patterns has offered important insights into western histories of the book. Paul Eggert for instance has explored the contribution made by Australian booksellers to the collapse of the three-decker novel in Britain in the late nineteenth-century, while Priya Joshi's landmark work demonstrates how Indian readers and the impact of their tastes and demands helped shape the production of the English novel in the Victorian period. ${ }^{8}$ This chapter seeks to add to this research through studying the sale and distribution of British publishing houses' ubiquitous "Colonial Editions."

\section{British publishers and the "Empire market"}

\footnotetext{
${ }^{6}$ See for instance Sydney Shep, 'Books Without Borders: The Transnational Turn in Book History,' in Robert Fraser and Mary Hammond, eds., Books Without Borders, 2 vols. (Houndmills: Palgrave Macmillan, 2008), 1: 13-37; Robert Fraser, Book History through Postcolonial Eyes (London: Routledge, 2008); Isabel Hofmeyr, The Portable Bunyan: A Transnational History of The Pilgrim's Progress (Princeton: Princeton UP, 2004).

${ }^{7}$ Isabel Hofmeyr, 'From Book Development to Book History - Some Observations on the History of the Book in Africa,' SHARP News 13.3 (2004), 3.

${ }^{8}$ Paul Eggert, 'Robbery Under Arms: The Colonial Market, Imperial Publishers, and the Demise of the ThreeDecker Novel,' Book History 6 (2003), 127-46; Prija Joshi, In Another Country: Colonialism, Culture, and the English Novel in India (New York: Columbia UP, 2002).
} 
In his chapter on "English books abroad" for The Book World of 1935, publishing statesman Stanley Unwin estimated that the "Export Trade" constituted "more than a third of the business done by my firm in normal times." 9 The Anglophone book market was a large global business in the early twentieth century with, as Unwin pointed out, "the circulation of English books ... not confined by any means to English-speaking peoples." ${ }^{10}$ Describing the market for the distribution of English books around the world, Unwin first considered the Continent and the Dutch trade which exported books "to Java and the Dutch East Indies"; then Palestine and Egypt; East and West Africa; South Africa ("a good market"); Australia ("a big consumer of English books - one of the largest overseas"); New Zealand; the South Sea Islands; Japan; China; India ("Here again the universality of the English language is an inestimable advantage"); America ("the most important country of all”); and Canada, Newfoundland and the West Indies. ${ }^{11}$ As Alison Rukavina has recently explored in The Development of the International Book Trade, 1870-1895 (2010), publishers and book trade agents "negotiated, collaborated, and competed as the international book trade developed ... [and] Increasingly .... thought about the world not as a vast geographical expanse but as a negotiable space in which commodities and ideas circulated."12 For British publishers like Unwin, the issue was how to stay ahead in an increasingly competitive global marketplace for English-language books.

The global trade in Anglophone literature at this time was dominated and fought over by British and American publishers. Due to their proximity, American publishing houses dominated the trade in imported books into Canada and the West Indies. This meant that the "Empire markets," so-called, were of crucial importance to British publishing houses, both in

\footnotetext{
${ }^{9}$ Unwin, 'English Books Abroad,' (see above, n. 1), p. 180.

${ }^{10}$ Ibid., p. 163.

${ }^{11}$ Ibid., p. 165, 169, 174-6.

12 Alison Rukavina, The Development of the International Book Trade, 1870-1895: Tangled Networks (Houndmills: Palgrave Macmillan, 2010), pp. 9-10.
} 
terms of trade access and distribution and in the publication rights granted in author's contracts. ${ }^{13}$ It is well known that the expansion of the international book trade in the late nineteenth-century went hand-in-hand with developments in global communications technologies and transportation, together with the unilateral trade policies of imperial expansion. ${ }^{14}$ But it is less often remembered that the British Empire was at its geographical height in the period 1900-40 and especially the years between the two World Wars. At the turn of the twentieth century, the British Empire covered one fifth of the inhabited world and its imperial influence expanded after the First World War into the Middle East, Africa and Melanesia. ${ }^{15}$ This gave British publishers important trade access to the huge Anglophone reading and book-buying markets of Australia and New Zealand, India and Canada, as well as many other territories and "Dominions." Books were shipped by steamship and rail, with overland telegraphs, submarine cables and wireless stations ensuring that advance marketing and publicity (as in the case of Bridge's Enchanter's Nightshade) could pay dividends to a book's initial subscription orders. ${ }^{16}$

The UK booktrade was keen to preserve a monopoly of trade in its colonies and Dominions and safeguarding British publishers' access to and control over the Empire markets constituted a substantial part of the day-to-day work of the publishers' trade body. Records pertaining to the Publishers' Association of Great Britain \& Ireland show that publishers were constantly warding off incursions "to British Empire rights" from American publishers issuing re-print editions in colonial markets or "selling the Australasian publishing rights direct to Australian publishers" (bypassing London), not to mention threats of piracy

\footnotetext{
${ }^{13}$ MS 2444 (see above, n. 2), CW 55/4. Publishers' Association of Great Britain \& Ireland, Group II (Fiction). Minutes, 12 December 1934. Publishers at this time would normally buy the book rights for "England, its Colonies and Dependencies," leaving authors free to negotiate separately the dramatic, cinematic, translation, and US rights.

${ }^{14}$ For an excellent summary see Rukavina (see above, n. 12), pp. 4-5.

${ }^{15}$ Richard Begam and Michael Valdez Moses, eds., Modernism and Colonialism. British and Irish Literature, 1899-1939 (Durham, N.C.: Duke UP, 2007), p. 2.

16 The trans-Pacific cable was laid in 1902, joining Western Canada to Queensland and New Zealand.
} 
and the infringement of copyright. ${ }^{17}$ At one single meeting of the fiction division of The Publishers' Association on 12 December 1934 for instance, approximately one third of the total business was devoted to attempts to regulate the colonial marketplace. Items for debate concerned preserving British publishers' control of the Australian marketplace (members were advised "not to undertake the British publication of any book of American origin, if the Australian market is excluded"); attempts to prevent the publication of complete book length novels as supplements to magazines (as was happening in the case of Australian Women's Weekly); shared agreements on of the price of colonial fiction; and a note to encourage all publishers "to endeavour to make arrangements to deliver books, particularly colonial editions, to exporters early in the week, if possible by not later than Wednesday," so as to prevent one exporter from taking competitive advantage over another. ${ }^{18}$ The list of items indicates how precarious were the efforts of British publishers to maintain a trade dominance in the "Empire markets."

The colonial booktrade from London operated through a complex distribution network of publishers and publishers' agents, colonial booksellers, libraries and wholesalers, as well as export booksellers, general exporters and shipping companies. Some colonial bookshops had direct accounts with British publishing houses, for which they needed a reference to open (one of the perks for colonial booksellers in buying imported books was the unusually long six month period of credit they had to pay the publisher back) but smaller bookshops were often advised to obtain books direct from a larger bookseller in the area who acted as a wholesaler for the publisher in that region. Many large book wholesalers, such as Australia's Gordon and Gotch Ltd, were involved in related trades including the distribution of stationery and fancy goods, print machinery, magazines, periodicals and newspapers.

\footnotetext{
${ }^{17}$ MS 2444 (see above, n. 2), CW 55/4. Publishers' Association of Great Britain \& Ireland, Group II (Fiction). Minutes, 12 December 1934.

${ }^{18}$ Ibid.
} 
Imported books were profitable commodities to such wholesalers, particularly when they could place large "marketing" orders with a publisher, through which they had exclusive sale of a particular title in that country and were enabled to receive hugely competitive discounts. ${ }^{19}$ In May 1938, Chatto's Harold Raymond wrote to George Hicks in Wellington regarding the increased activity of the rival firm of Whitcombe \& Tombs concerning the "sale of markets" in New Zealand. ${ }^{20}$ Where they bought the market of a 7/6d. novel, Raymond noted, Whitcombe \& Tombs's price was 2/9d. After making the payments due to their representatives, town traveller, and author royalties, this left Chatto "with very little more than 2/- out of which to manufacture the book and take our profit."21 "Obviously it would not pay us to offer them our best sellers like "Enchanter's Nightshade," Raymond continued, "of which they bought over 400 copies on subscription at the usual 3/3d.; on the other hand, if the granting of the New Zealand market has no attendant disadvantages, the purchase of even 100 or 150 copies of a novel ... by a moderate seller is decidedly attractive, even at 2/9d." 22

With other large marketing orders the sums the publisher received per copy could be even lower. In the 1930s Chatto regularly sold large bulk orders of colonial editions to Musson's Book Company in Toronto at the discounted price of $2 / 4 \mathrm{~d} .{ }^{23}$ The Canadian domestic book market was in a double bind in this period, exposed to imports of cheap American editions and often unauthorised reprints, but itself subject to British imperial copyright legislation and protectionist trade policies. ${ }^{24}$ In September 1930, Leonard Woolf

\footnotetext{
${ }^{19}$ See Denis Cryle, 'Gordon and Gotch from the 1940s to the Present: Regional Distribution and Integration in Australia, New Zealand and Papua New Guinea,' in Paul Eggert and Elizabeth Webby, eds., Books and Empire: Textual Production, Distribution, and Consumption in Colonial and Postcolonial Cultures (Wagga Wagga, NSW: Bibliographical Society of Australia and New Zealand, 2004), pp. 17-26 (p. 19-20).

${ }^{20}$ Harold Raymond to George Hicks, 4 May 1938. MS 2444 (see above, n. 2), CW 77/20.

${ }^{21}$ Ibid.

${ }^{22}$ Ibid.

${ }^{23}$ MS 2444 (see above, n. 2), Profit \& loss ledger 1927-33, CW B/3/2.

${ }^{24}$ See also Catherine Seville, 'Novelists, Literary Property, and Copyright,' in The Oxford History of the Novel in English, 12 vols. (Oxford: Oxford UP, 2011-), 4: 22-35 (p. 22-3).
} 
wrote to one of his bestselling authors, Vita Sackville-West, to say that he had agreed to give further discounts to Hogarth's Canadian representative because of the American's ability to push prices down and make the price of imported British books into Canada uncompetitive. Again this had wider impact on the relations between British publishers and the diffuse transnational networks of trade:

We have had some rather big orders from Australia and have sold 24,800 [of The Edwardians]. ... Our Canadian agent is rather upset that we have not stood upon our prior rights, but I have told him that that is not possible. We have to give discount ... already on colonial books and he presses me to give him ... [more] on The Edwardians so that he may undersell Doran. Under the circumstances I have agreed, but it is rather a nuisance as we shall also have to give it for the big Australian orders. ${ }^{25}$

There was no Net Price Agreement as such to cover the resale of Colonial editions of 7/6d. fiction but the Publishers' Association made continual agreements to re-stipulate minimum terms. In 1934 for instance after reports that "certain publishers were supplying Colonial editions for resale in Australia and New Zealand at 2/6d. or 2/8d.," the Publishers' Association sought general agreement not to supply the overseas trade $7 / 6 \mathrm{~d}$. fiction for resale at less than 3/3d. (with $6 /-$ fiction at 3/-; 3/6d. at1/9d). ${ }^{26}$

\section{Colonial Editions and patterns of distribution}

The colonial book trade had long been an important part of "the book world" for British fiction publishers. In the nineteenth century a number of firms began distinct series, or libraries, targeted at the colonial market after the passing of the British Copyright and Customs Act (1842) which attempted to provide protection for British books against piracy

\footnotetext{
${ }^{25}$ Leonard Woolf to Vita Sackville-West, 17 September 1930. Reading, UoR, Records of the Hogarth Press, MS 2750/416. Quoted with permission from The University of Sussex and The Society of Authors as the Literary Representative of the Estate of Leonard Woolf, and The Random House Group Ltd.

${ }^{26}$ MS 2444 (see above, n. 2), CW 55/4. Publishers' Association of Great Britain \& Ireland, Group II (Fiction). Minutes, 18 July 1934.
} 
throughout the empire. The most successful of these series belonged to Macmillan who launched their Colonial Library in 1886 (this was renamed the "Macmillans Empire Library" in 1913 and the more politically innocuous "Overseas Library” in 1937), issuing 1,738 titles up until its end in $1960 .{ }^{27}$ But the trade in English-language books abroad was not limited to particular publishers' series like these. As Unwin noted in The Truth about Publishing, "most novels and some other books are issued in colonial editions." 28 A ubiquitous, though regularly overlooked part of the twentieth-century book trade, colonial editions formed part of the publisher's ordinary first edition. Long surrounded in "bibliographical inexactitudes," colonial editions were cheaper versions of a book title, printed on thinner paper and produced from the same typeset as the "English" or Home edition. ${ }^{29}$ They are identified in publisher's records through the booktrade's abbreviation of "C.C." (colonial cloth), a less substantial cloth binding than that used for the home edition. Similar in premise to the Tauchnitz editions of British and American authors (1841-1955) that were produced solely for the continental market and not resold in Britain, colonial editions were issued specifically for colonial distribution and were not to be circulated, sold or imported into the British Isles or America. They were marked as Colonial editions on either the title-page or jacket and were distributed throughout the British Empire in large quantities, reaching readers in the major Anglophone book markets of India, Australia, New Zealand, Canada, and South Africa. Over time they gradually became indistinguishable from home editions in appearance, with only stamps on titlepages or jackets to indicate that they were editions for "overseas." They remained a distinct part of the British book trade until the mid-1960s. ${ }^{30}$

\footnotetext{
${ }^{27}$ For recent work on the Macmillan Colonial Library see Robert Fraser, 'Leonard Bast's Library: Aspiration, Emulation and the Imperial National Tradition,' in John Spiers, ed., The Culture of the Publisher's Series, 2 vols. (Houndmills: Palgrave Macmillan, 2011), 2: 117-33; and Shafquat Towheed, 'Negotiating the List: Launching Macmillan's Colonial Library and Author Contracts,' in Spiers, ed., The Culture of the Publisher's Series, 2: 134-51.

${ }^{28}$ Stanley Unwin, The Truth about Publishing, 4th ed. (London: Allen \& Unwin, 1946), p. 85.

${ }^{29}$ Graeme Johanson, A Study of Colonial Editions in Australia, 1843-1972 (Wellington, N.Z.: Elibank Press, 2000), p. 14.

${ }^{30}$ Ibid., p. 51.
} 
Colonial editions formed a substantial part of the publisher's first print run, making up on average between $20 \%$ and $30 \%$ of the total book production and sales of a typical first edition. ${ }^{31}$ To illustrate this with some examples from the archives of British Publishing and Printing, if we take the sale and distribution of the novels of a popular, bestselling author of the 1930s like Ann Bridge as illustration, we see a consistent proportion of between one fifth and a quarter of the total copies of her first print runs being shipped out to the colonies. The figures in Chatto \& Windus's Profit \& Loss account for Bridge's first novel, Peking Picnic (1932) - an exciting tale of diplomatic high life, politics and expat-society in China - are as follows:

\begin{tabular}{|l|l|l|}
\hline $\begin{array}{l}\text { Number of copies printed } \\
(14,000 \text { total })\end{array}$ & $\begin{array}{l}\text { Income received } \\
(£, \text { shillings, } \\
\text { pence })\end{array}$ & Distribution \\
\hline 116 free & $£ 1232 / 17 / 13$ & $\begin{array}{l}\text { Home sales to wholesale booksellers } \\
\text { and libraries }\end{array}$ \\
\hline 5,191 sold @ 4/9d. & $£ 648 / 15 /-$ & Home sales to retail booksellers \\
\hline 2,595 sold @ 5/- & $£ 521 / 6 /-$ & Colonial editions \\
\hline 3,208 col. @ 3/3d. & $\begin{array}{l}\text { Books bound, remaining at the } \\
\text { publishers }\end{array}$ \\
\hline 140 bound on hand & $\begin{array}{l}\text { Paper sheets (books without binding), } \\
\text { remaining at the publishers }\end{array}$ \\
\hline 2,750 quires on hand & & \\
\hline
\end{tabular}

[INSERT Table 2.1. Sale and distribution figures for Ann Bridge, Peking Picnic, by 24 October 1933. Published 15 September 1932 at 7/6d., Cr 8vo. 336 pp.] $]^{32}$

Six editions of Peking Picnic were published during its first year in print (four editions of 2,000 copies; two editions of 3,000 copies), with the total number of 14,000 copies printed representing a large print run for a new, unknown author (2,000 to 3,000 copies was more typical in such a case). The book's status as a bestseller was boosted by success in the

\footnotetext{
${ }^{31}$ Drawing on Unwin's figures in The Truth about Publishing, Johanson puts this slightly higher at between $27 \%$ and $33 \%$. Johanson, Colonial Editions (see above, n. 29), p. 83-4.

${ }^{32}$ MS 2444 (see above, n. 2), Profit \& loss ledger 1927-33, CW B/3/2, f. 515-6.
} 
American market, where it was published prior to the British edition and named winner of the Atlantic Monthly, a recently inaugurated biennial prize for fiction. ${ }^{33}$ The geographical distribution of the first British print run was however typical of other novels of the time. Over two thirds of the 10,994 copies sold went to the home markets of commercial circulating libraries, public libraries, book clubs and bookshops (a total of 7,786: 71\%), and just under one third of the copies sold in the first year (3,208 copies: 29\%) (roughly half the amount of the home edition) were bound for the colonies. ${ }^{34}$

This distributive spread remained similar for Bridge's subsequent works published by Chatto \& Windus in the 1930s. In the case of The Ginger Griffin (1934), a Book Society "Choice" for June 1934, 44\% (8,333) of the first edition copies sold in its first three months went to libraries and bookshops in the UK, $22 \%$ (4,272 copies) were sold as colonial editions ${ }^{35}$ For her next bestseller, Illyrian Spring (1935) - a novel set in Dalmatia which apparently did much to boost tourism to the Adriatic - and again a Book Society "Choice," 16,121 copies went to the home markets ( $61 \%$ of copies sold in the first seven months) and 4,861 (18\%) were sold as colonial cloth. ${ }^{36}$ Here also we find a separate ledger entry referring to the stock purchased by Gordon \& Gotch, a major Australian book distributor. Placing a large "marketing” order for Illyrian Spring, Gordon \& Gotch purchased 1,561 colonial editions for the Australian market from Chatto at 3/-, undercutting the regular colonial cloth sales of the novel at 3/3d. Sales of Enchanter's Nightshade were - as expected if we recall the telegram with which this chapter opened - predictably large. As Table 2.2 shows, in under eighteen months, 12,390 copies of the book (49\% of sales) had been sold to libraries and bookshops in the UK, with the initial order from the Book Society adding up to just over

\footnotetext{
${ }^{33}$ Bridge, Fact and Fictions (see above, n. 3), p. 37-9.

${ }^{34}$ These figures referring to Bridge, and those which follow, are calculated on total number of copies sold (rather than printed), discounting review copies and "on hand" stock.

${ }^{35}$ MS 2444 (see above, n. 2), Profit \& loss ledger 1933-1945, CW B/3/3, f. 101-2.

${ }^{36}$ Ibid., f. 237-8. See Bridge, Facts and Fictions (see above, n. 3), p. 45.
} 
7,100 copies. 6,019 copies ( $24 \%$ of sales) - again roughly half the amount of the "home" edition - were distributed in the colonies. Whitcombe \& Tombs of New Zealand which, according to Unwin, "dominated" New Zealand trade "with branches almost everywhere except on the west coast of the South Island," bought over 400 copies on subscription at the usual colonial rate of 3/3d. ${ }^{37}$ Again Gordon \& Gotch placed a large "marketing" order for 1,128 colonial editions at 3/- for wholesale distribution in the Australian marketplace.

\begin{tabular}{|c|c|c|}
\hline $\begin{array}{l}\text { Number of copies printed } \\
(30,100 \text { total })\end{array}$ & $\begin{array}{l}\text { Income received } \\
(£, \text { shillings, pence) }\end{array}$ & Distribution \\
\hline 150 free & & Review copies \\
\hline 4,130 sold@ 4/9d. & $£ 980 / 17 / 6$ & $\begin{array}{l}\text { Home sales to wholesale } \\
\text { booksellers and libraries }\end{array}$ \\
\hline 8,260 sold @ 5/- & $£ 2065 /-/-$ & Home sales to retail booksellers \\
\hline 4,891 col.@3/3d. & $£ 794 / 15 / 9$ & Colonial editions \\
\hline 1,128 Gordon Gotch @ 3/- & $£ 169 / 4 /-$ & $\begin{array}{l}\text { Colonial editions, "marketing" } \\
\text { order to Australia }\end{array}$ \\
\hline 7,104 Book Soc. @ 3/41/2 & $£ 1198 / 16 /-$ & Book Society Ltd. \\
\hline 337 bound on hand & & $\begin{array}{l}\text { Books bound, remaining at the } \\
\text { publishers }\end{array}$ \\
\hline 4,100 quires on hand & & $\begin{array}{l}\text { Paper sheets (books without } \\
\text { binding), remaining at the } \\
\text { publishers }\end{array}$ \\
\hline
\end{tabular}

\section{[INSERT Table 2.2 Sale and distribution figures for Ann Bridge, Enchanter's}

\section{Nightshade, by 31 March 1939. Published 1 November 1937 at 7/6d., Cr 8vo. 408 pp.] ${ }^{38}$}

This proportion of between one fifth and a quarter of a title's first print run bound for the colonial marketplace seems fairly standard for new works of fiction in this period, though of course there were many variations. Of Aldous Huxley's Brave New World, which Chatto

\footnotetext{
${ }^{37}$ Stanley Unwin, 'British Books Overseas,' in John Hampden, ed., The Book World Today: A New Survey of the Making and Distribution of Books in Britain (London: Allen \& Unwin, 1957), pp. 212-23 (p. 217).

${ }^{38}$ Profit \& loss (see above, n. 35), f. 423-4.
} 
published in 1932 , only ten percent $(2,149$ copies) of the first print run of the $7 / 6 \mathrm{~d}$. edition (a total of 20,700 copies) were sold as colonial editions at 3/3d., but this becomes slightly larger (13\%) when the 520 copies sold directly to Musson's Book Company for wholesale in Canada (at the larger discounted price of $2 / 8 \mathrm{~d}$.) are factored in. ${ }^{39}$ The much lower proportion of copies going to the colonial marketplace here is explained by the bans on Brave New World in various parts of the world. Letters in the Chatto archive to Hicks, Smith \& Wright from 1937, for instance, note the publisher's relief that recent book bans in Australia have been lifted: "Hats off to Australia ... We shall next hear of you prescribing Ulysses as a primer for elementary schools. The orders for Brave New World have been very welcome indeed" writes Harold Raymond to Joseph Hicks in April of that year. ${ }^{40}$ Other Chatto authors, at least if we take the initial distribution of first edition sales as evidence (there is of course the wider book market of borrowing, second-hand sales and exchange which muddies this picture) remained less popular in the colonies. The novels of Sylvia Townsend Warner for instance consistently failed to pick up in the colonial marketplace, with the colonial edition sales of her early novels averaging out at around ten percent of her total print run. ${ }^{41}$

The colonial marketplace was not only important to large, well-established British publishing firms like Chatto \& Windus, Bentley, and Macmillan. Colonial editions also made up a substantial proportion of the business of smaller publishing houses, including publishers closely associated with modernism like Leonard and Virginia Woolf's The Hogarth Press (established 1917). Recent work in modernist studies has explored how "modernist literary practice might be related, both formally and thematically, to the experience of empire." ${ }^{42}$ According to this view, the aesthetic innovations and formal experimentations of literary modernism are deeply related to writers' ambivalence towards colonialism. But it is less often

\footnotetext{
${ }^{39}$ Profit \& loss (see above, n. 23), f. 443-4.

${ }^{40}$ Harold Raymond to Joseph Hicks, 14 April 1937 (see above, n. 2).

${ }^{41}$ Profit \& loss (see above, n. 23 and 35).

${ }^{42}$ Begam and Valdez Moses, eds., Modernism and Colonialism (see above, n. 15), p. 1.
} 
acknowledged that modernist literary practice was also deeply related materially and economically to Empire through the sale and distribution of books and magazines. New titles published by the Hogarth Press for instance were widely sold and distributed throughout the "Empire markets." A series of Order Books in the Hogarth Press archive which contain detailed information as to the customers and orders of Hogarth Press titles enable us to appreciate the significance of the colonial marketplace to the Woolfs, where again as a proportion of the sale and distribution of the first print run, editions for the colonies generally made up around twenty percent of a title's sales. ${ }^{43}$

Key booksellers, wholesalers and distributors in the colonial marketplace emerge from these detailed records which give us a rich sense of the geographical distribution and spread of the first editions of Hogarth Press titles over a longitudinal period of time. To take The Years (1937), one of Virginia Woolf's bestsellers, as an example: here we have sales and distribution figures for the $8 / 6 \mathrm{~d}$. edition (sold in colonial cloth to the retailer at $4 / 3 \mathrm{~d}$.) for the period from early March 1937 to the 3 January 1944 (over 2,000 records of sale). ${ }^{44}$ Books for colonial and overseas customers were packaged up and dispatched first (the majority on 3 March), two weeks before the publication date of 15 March. A sample of the names of some of these customers reveals a tantalising glimpse into a network of colonial exchange and circulation that deserves much further study: Argus South African, Burma Book Club, New South Wales Bookstore, Darter Brothers (Cape Town), Taraporevala, Anglo-Egyptian bookshop. Up until May 1943, when the last order for a colonial edition came in, key buyers from the colonies in terms of scale and repeat orders included Australia's Angus \& Robertson and Gordon \& Gotch (who took an initial subscription order of 116 copies); the Oxford

\footnotetext{
${ }^{43}$ MS 2750 (see above, n. 25) /A/16-31. The analysis in this section has benefited from the painstaking transcription work of Dale Hall, Andrew Reay and Sophie McKenna. We would like to acknowledge the University of Reading's assistance in financing their Undergraduate Research Opportunities Projects. ${ }^{44}$ MS 2750 (see above, n. 25) /A/27. Order Book: Novels Sackville-West \& Woolf.
} 
Bookstore \& Stationery company (an Indian book-store chain with outlets in Calcutta, Delhi, Lahore, Meerut); and Whitcombe \& Tombs in New Zealand.

We must beware of moving too quickly from evidence of sales and distribution to the colonies to discussions of readership or reading experience, from what Priya Joshi reminds us is evidence of production in the textual archive and not consumption or "actual readers."45 More needs to be done to look at the patrons of Darter Brothers in Cape Town, or of the New South Wales Bookstall, or India's Oxford Bookstore \& Stationery Company, to begin to understand how Woolf's books were read and received in these different colonial markets and by different individuals and groups of readers. Such work would also have to take account of the cheap editions market and the ways in which texts circulate and are recirculated within any given community, including informal methods of borrowing and loans from individuals, libraries and clubs. But the evidence contained in the Hogarth Press Order Books marks a start in researching Woolf's colonial readers and readership, complementing and adding to recent work on her reception in Europe, and reminding us of the much wider global networks in which Hogarth Press titles, like the works of other contemporary publishers, were circulated. ${ }^{46}$

\section{British distributors abroad}

How should we account for reading patterns as evidenced in the sale of colonial cloth editions? Recent research by Robert Fraser on the titles in Macmillan's Colonial Library has found a "staple diet of middle-brow contemporary novels produced by and large in the form of cheap reprints of Macmillan's domestic fiction list." ${ }^{47}$ Priya Joshi and Graeme Johanson’s

\footnotetext{
45 Priya Joshi, 'Culture and Consumption: Fiction, the Reading Public and the British Novel in Colonial India,' Book History 1.1 (1998), 196-220, there 197.

${ }^{46}$ See for instance Mary Ann Caws and Nicola Luckhurst, The Reception of Virginia Woolf in Europe (London: Bloomsbury, 2008); and Helen Southworth and Claire Battershill, 'The Hogarth Press in a Global Context,' in Jessica Berman, ed., Blackwell Companion to Virginia Woolf (Oxford: Wiley-Blackwell, forthcoming*).

${ }^{47}$ Fraser, 'Leonard Bast's Library' (see above, n. 27), p. 124.
} 
landmark studies of popular authors and reading patterns in colonial India and late nineteenth and early twentieth-century Australia respectively have made comparable discoveries.

Drawing upon a variety of library catalogues and statistics on borrowing from Indian public libraries from the mid to late nineteenth-century, Joshi identifies G. W. M. Reynolds as "the most persistently popular of these novelists in India" (others included Sir Walter Scott, Edward Bulwer-Lytton, Marie Corelli, Francis Marion Crawford) because of the symbolic affinities that Indian readers' found with the genres of melodrama and romance. ${ }^{48}$ Graeme Johanson points to best-selling authors in Australia - Guy Newell Boothby, Edward Phillips Oppenheim and Francis Marion Crawford - arguing that they "used repetition of timehonoured themes - not to mention stereotyped titles - about power-play, crime, human foibles, money, picaresque excitement, and romance, thus promising wide appeal." ${ }^{49}$ Joshi and Johanson are concerned with Indian and Australian readers respectively, and Joshi's work in particular has been celebrated for its stress on consumption rather than my emphasis on production and distribution here. But what is striking to her analysis of "how literate Indians addressed, absorbed, consumed, and otherwise responded to the world of textuality and print that originated in and arrived from Britain," are the some of the apparent similarities between the tastes of readers in the colonies and what British publishers would often describe as the typical library reader at home. ${ }^{50}$ It is no coincidence that these popular authors, many of whom are of course no longer widely known, were also widely read by British readers in the "home" market and avidly consumed in public and circulating libraries of the time. ${ }^{51}$

The connections between popular authors in the colonies and popular reading tastes at

\footnotetext{
48 Joshi, In Another Country (see above, n. 8), pp. 74, 83-92.

49 Johanson, Colonial Editions (see above, n. 29), p. 40.

${ }^{50}$ Joshi, p. xvii.

${ }^{51}$ See Mary Hammond, "The Great Fiction Bore": Free Libraries and the Construction of a Reading Public in England, 1880-1914,' Libraries \& Culture 37.2 (2002), 83-108; and Nicola Wilson, 'Libraries, Reading Patterns and Censorship', in The Oxford History of the Novel in English, 12 vols. (Oxford: Oxford UP, 2011-), 4: 36-51.
} 
home brings me to another aspect of the colonial book trade. While, as I have said, many colonial bookshops (both large and small) had direct accounts with British publishing houses, another aspect of the trade that we find evidence of in the publisher's archive is the British distributors and libraries who operated across the "Empire markets." This includes large global distributors like Dawson and Simpkin Marshall who had major export and overseas departments, as well as circulating libraries, bookshops and book clubs based in the UK who supplied books to readers and members based overseas. The Hogarth Press Order Books, for instance, show that the major British circulating libraries of the period - W.H. Smith, Boots Book-lovers' Library, Mudie's Select Circulating Library, Harrods and the Times Book Club - were all significant purchasers of books in colonial cloth. These libraries, all of which cultivated an atmosphere of distinction, operated upon a subscription basis and were keen to deliver good customer service. As the Times Book Club explained to Macmillan in 1932 "with regret that you find yourselves unable to supply further copies of The Fountain [by Charles Morgan] in a colonial edition," "we require this book mainly for Clubs, Libraries and individual customers who place standing orders with us for regular supplies of the latest books. ... Many of our clients find it convenient to purchase their books through us because they are stationed in remote places where they cannot obtain local supplies." 52

Providing orders to these suppliers at the much more favourable colonial terms proved a continual headache for British publishers. There was much debate over what constituted legitimate colonial trade amongst the members of the Publishers' Association in this period, and classified lists of exporters entitled to wholesale terms were regularly revised. In confidential discussions for new price schemes of colonial fiction in 1934, the Publishers' Association agreed that English booksellers and wholesalers should not buy colonial fiction at less than $3 / 3 \mathrm{~d}$., and that a few select libraries and retailers, "in addition to recognised

\footnotetext{
${ }^{52}$ Times Book Club to Macmillan, 17 February 1932. Reading, UoR, Macmillan archive, MS 1089, 124/135.
} 
exporters should be regarded as entitled to be supplied with Colonial editions without question." ${ }^{\text {53 }}$ This included Mudie’s Library, Simpkin Marshall (Export and overseas departments), W. H. Smith, and the Times Book Club. Steamship companies could be supplied with colonial editions "on condition that such Colonial Editions are only for use or sale outside this country." ${ }^{, 54}$ Due to the huge scale of their orders (running into several thousands for a monthly "Choice") and the large discounts they already received from the publishers, the position of the Book Society Ltd was more complex. A note added, "the Book Society, Ld., may be supplied with Colonial editions of books other than 'chosen' books, but at not less than $3 / 9$, and only providing the country of destination is given when requested." 55

The production of colonial editions lasted until the 1960s and early '70s, and British cartelisation of the book trade in the former colonies went well beyond the historical period of Empire. In 1947, publishers adopted the British Traditional Market Agreement which attempted to reassert British distribution rights in the "Commonwealth and Empire as politically constituted" after the incursions of American publishers into these markets during the Second World War. ${ }^{56}$ This, as Graeme Johanson points out, was an instrument of de facto colonialism which "lasted until 1976, well beyond the collapse of the political Empire" and had huge implications on local and indigenous publishing scenes. ${ }^{57}$ With the Traditional Market Agreement in place, British publishers were able to devote more systematic attention to the scale and reach of export operations. As Unwin notes in Hampden's second edited

\footnotetext{
${ }^{53}$ MS 2444 (see above, n. 2), CW 55/1. Publishers' Association of Great Britain \& Ireland, Group II (Fiction). Colonial Fiction. New Prices. Revised and corrected June 1934, p. 2.

${ }^{54}$ Publishers' Association of Great Britain \& Ireland, Group II (Fiction). Minutes, 20 May 1931 (see above, n. 53).

${ }^{55}$ Publishers' Association of Great Britain \& Ireland, Group II (Fiction). Colonial Fiction. New Prices (see above, n. 53).

56 Johanson, Colonial Editions (see above, n. 29), p. 22.

${ }^{57}$ Ibid., p. 23. See also James McCall, 'Books and the Nation: Aspects of Publishing and National Identity,' in Paul Eggert and Elizabeth Webby, eds., Books and Empire: Textual Production, Distribution, and Consumption in Colonial and Postcolonial Cultures (Wagga Wagga, NSW: Bibliographical Society of Australia and New Zealand, 2004), pp. 142-7.
} 
compendium, "far more attention is given to export trade than was the case when The Book World was published in 1935. Since 1947 the Publishers Association has had an Export Research Department doing invaluable work. Every market is carefully studied. Obstacles to the free flow of books are carefully charted." ${ }^{58}$ An interesting table in the appendix lists the approximate value of book trade exports to different countries. For the figures available in 1954-5, Australia boasts by far the largest turnover for the sale of imported British books; America, South Africa and India are the next largest markets in descending order of profit. ${ }^{59}$ Large sales of new paperback series like the much-respected Penguins continued to boost the sale and distribution of British books around the world. As Unwin admitted, "Since many low-priced textbooks and paper-covered books are included, and many dearer books have to be sold at special discounts, it is possible that half the books printed in Britain today are sold overseas. $" 60$

This chapter has attempted to offer a nuanced understanding of the trade in colonial editions in the first half of the twentieth century, one that goes beyond the one-way traffic of Unwin's "export" model to recognise the disruptions and multivalences inherent in transnational networks of colonial traffic and exchange. Representing a significant market share to the print runs of new works of fiction published in this period, colonial wholesalers, distributors and, by implication, their audiences, yielded a certain amount of leverage in British publishing houses, continually pushing prices down on the one hand, and able to influence trade on the other side of the world with the other. The implications of this large global readership in the minds of authors and writers goes beyond my scope here, as does a more detailed examination of the reception of colonial editions in the markets, bookshops and reading groups where they were clearly sought out. Nevertheless this chapter hopes to have

\footnotetext{
${ }^{58}$ Unwin, 'British Books Overseas' (see above, n. 37), p. 222.

${ }^{59}$ John Hampden, ed., The Book World Today: A New Survey of the Making and Distribution of Books in Britain (London: Allen \& Unwin, 1957), Appendix, p. 233.

${ }^{60}$ Unwin, 'British Books Overseas' (see above, n. 36), p. 223.
} 
indicated some avenues for further research and to have made clear the important role played by colonial editions and trade in the shaping of literary history and print culture in its broad transnational past.

\section{Acknowledgements}

With thanks to the estate of Ann Bridge and Peters, Fraser and Dunlop for permission to access material relating to Bridge in the archives of British Publishing and Printing at the University of Reading. Quotes and information from the Chatto \& Windus archive are from The Random House Group Archive and Library of the University of Reading and reproduced with thanks to The Random House Group Ltd. 